\title{
L-carnitine supplementation descreases hepatic triglyceride accumulation in Holstein cows during the transition period
}

\section{La suplementación con L-carnitina disminuye la acumulación de triglicéridos hepáticos en vacas Holstein durante el periodo de transición}

\section{Suplementação com L-carnitina diminui o acúmulo de triglicerídeos hepáticos em vacas Holandesas durante o período de transição}

Rubén D Galvis*; Liset V Madrid ${ }^{1}$; Nicolás Ramírez-Vásquez².

\footnotetext{
${ }^{1}$ Grupo de Investigación sobre Interacciones Nutricionales, Metabólicas y Reproductivas en Bovinos, Departamento de Producción Animal, Universidad Nacional de Colombia, Sede Medellin, Colombia.

${ }^{2}$ Linea de Investigación en Medicina Bovina, Grupo de Investigación Centauro, Escuela de Medicina Veterinaria, Facultad de Ciencias Agrarias, Universidad de Antioquia, Medellín, Colombia.
}

(Received: December 5, 2017; accepted: February 27, 2019)

To cite this article:

Galvis RD, Madrid LV, Ramírez-Vásquez N. L-carnitine supplementation decreases hepatic triglyceride accumulation in Holstein cows during the transition period. Rev Colomb Cienc Pecu 2019; 32(3):166-174.

DOI: https://doi.org/10.17533/udea.rccp.v32n3a01

(cc) $\mathbf{B Y}-\mathrm{Ne}-\mathbf{S A}$ This work is licensed under a Creative Commons Attribution-NonCommercial-ShareAlike 4.0 International License.

* Corresponding author: Calle 59a No 63-20 Bloque 50, Oficina 202. Medellín, Colombia. E-mail: rdgalvis@unal.edu.co 
Abstract

Background: The increased use of body reserves observed during peripartum leads to higher needs of L-carnitine by cows, which is restrictive under the production conditions of Colombian high tropics. Objective: To evaluate the lipotropic potential of L-carnitine in Holstein dairy cows during the transition period to lactation. Methods: Twenty-one Holstein cows were fed 0, 100, or $200 \mathrm{~g} / \mathrm{d}$ L-carnitine fumarate from d 260 of gestation to d 20 postpartum. Hepatic triacylglycerides concentration, total carnitine, free carnitine, acylcarnitine, and serum levels of non-esterified fatty acids (NEFA), $\beta$-hydroxybutyrate $(\beta$-HB) and urea were determined by spectrophotometry. Repeated measures analysis was used to determine the effects of dose, measurement period, and their interactions. Results: Hepatic triglycerides and the different forms of carnitine showed no difference between sampling periods $(\mathrm{p}>0.05)$. Hepatic triglycerides concentration was low and decreased in response to $200 \mathrm{~g} / \mathrm{d}$ L-carnitine fumarate supplementation $(\mathrm{p}<0.05)$. This decrease in hepatic triglycerides could be due to increased fatty acid oxidation. L-carnitine supplementation significantly increased $(\mathrm{p}<0.05)$ blood urea concentration, possibly through stimulation of the urea cycle, as previously described in other species. Conclusion: Supplementation with L-carnitine decreased the hepatic concentration of triglycerides, possibly due to increased liver oxidation of fatty acids.

Keywords: dairy cows; lipid metabolism; L-carnitine; lipidosis; lipotropic factors; metabolic disorders; peripartum.

\section{Resumen}

Antecedentes: El incremento en la utilización de reservas corporales durante el periparto en vacas exige una alta disponibilidad de L-carnitina, la cual puede ser limitante bajo las condiciones propias de producción del trópico alto colombiano. Objetivo: Evaluar el potencial lipotrópico de la L-carnitina en vacas lecheras Holstein durante el periodo de transición a la lactancia. Métodos: Se suministraron dosis de 0, 100 y $200 \mathrm{~g} / \mathrm{d}$ de fumarato de L-carnitina a 21 vacas Holstein a partir del d 260 de gestación y hasta el d 20 postparto. Se determinaron las concentraciones hepáticas de triacilglicéridos, carnitina total, carnitina libre y acil carnitina, y las concentraciones plasmáticas de ácidos grasos no esterificados (NEFA), $\beta$-hidroxibutirato ( $\beta$-HB) y urea. Un análisis de medidas repetidas fue usado para determinar los efectos de la dosis, el periodo de medición, y sus interacciones. Resultados: Las concentraciones hepáticas de triglicéridos y de las diferentes formas de carnitina no difirieron significativamente $(\mathrm{p}>0,05)$ entre periodos de muestreo. La concentración hepática de triglicéridos fue baja, y mostró una disminución significativa $(\mathrm{p}<0,05)$ en respuesta a la suplementación con $200 \mathrm{~g} / \mathrm{d}$ de fumarato de L-carnitina. La disminución en los triglicéridos hepáticos podría deberse a un aumento en la oxidación de ácidos grasos. La suplementación con L-carnitina aumentó significativamente $(\mathrm{p}<0,05)$ la concentración de urea en sangre, posiblemente a través de un mecanismo de estimulación del ciclo de la urea, descrito previamente en otras especies. Conclusión: La suplementación con L-carnitina disminuyó la concentración hepatica de trigliceridos, debido posiblemente a un aumento en la oxidación de ácidos grasos en hígado.

Palabras clave: factores lipotrópicos; lipidosis; L-carnitina; metabolismo lipídico; periparto; trastornos metabólicos; vacas lecheras.

\section{Resumo}

Antecedentes: $\mathrm{O}$ aumento do uso de reservas corporais durante o periparto requer alta disponibilidade de L-carnitina, que pode ser limitante nas condições de produção no trópico alto colombiano. Objetivo: Avaliar o potencial lipotrópico da L-carnitina em vacas leiteiras Holstein durante o período de transição para a lactação. Métodos: Quantidades de 0, 100 e $200 \mathrm{~g} / \mathrm{d}$ de fumarato de L-carnitina foram administradas a 21 vacas holandesas durante o d 260 da gestação e até ao d 20 pós-parto. Foram determinadas as concentrações hepáticas de triacilglicerídeos, carnitina total, carnitina livre e acil carnitina e as concentrações plasmáticas de ácidos graxos não esterificados (NEFA), $\beta$-hidroxibutirato $(\beta-\mathrm{HB})$ e ureia. Uma análise das medidas repetidas foi usada para determinar os efeitos da dose, período de medição e suas interações. Resultados: As concentrações hepáticas de triglicerídeos e as diferentes formas de carnitina não diferiram significativamente entre os períodos de amostragem $(p>0,05)$. A concentração hepática de triglicerídeos foi baixa e mostrou diminuição significativa $(\mathrm{p}<0,05)$ em resposta à suplementação com $200 \mathrm{~g} / \mathrm{d}$ de fumarato de L-carnitina. A diminuição dos triglicerídeos hepáticos pode ser devido a um aumento na oxidação de ácidos graxos. A suplementação com L-carnitina aumentou significativamente $(\mathrm{p}<0,05)$ a concentração de ureia no sangue, possivelmente através de um mecanismo de estimulação do ciclo da ureia previamente descrito em outras espécies. Conclusão: A suplementação com L-carnitina diminuiu a concentração hepática de triglicerídeos, possivelmente devido ao aumento da oxidação de ácidos graxos no fígado.

Palavras-chave: distúrbios metabólicos; fatores lipotrópicos; lipidose; L-carnitina; metabolismo lipídico; periparto; vacas leiteiras. 


\section{Introduction}

Dairy cows mobilize body reserves to meet energy demands on the days before parturition and the first three weeks post-calving. As a result, plasma concentration of non-esterified fatty acids (NEFA) increase and are oxidized in the liver. Increased fatty acid (FA) oxidation depends, among others, on augmented carnitine palmitoyl transferase-I (CPT-1) activity, which increases by $49 \%$ on day one prepartum (Dann et al., 1999). This implies a proportional increase in the substrates (FA and carnitine) used by the enzyme CPT-1. Mobilization of protein reserves provides the necessary precursors for L-carnitine synthesis (Bell et al., 2000). Under the prevailing nutritional conditions of dairy farms in the Colombian high tropics, it is likely that the negative energy balance (NEB) during the transition period forces cows to increase the use of amino acids for energy, diminishing the lysine and methionine pools, which are substrates for carnitine synthesis. Under these conditions, significant associations have been reported between NEB and hepatic ammonium concentration, and between liver ammonium and pyruvate, suggesting increased usage of amino acids from body reserves as an energy source (Galvis et al., 2010). This situation can decrease carnitine precursors, possibly limiting CPT-1 activity. Under in vitro conditions, palmitate oxidation increases when bovine hepatocytes are supplemented with carnitine. Adding a CPT-1 inhibitor stops this increase, demonstrating how sensitive CPT-1 is to carnitine availability and suggesting that carnitine supplementation could modulate the enzyme activity (Drackley et al., 1991a). It is also known that carnitine supplementation in dairy cows produces variable results depending on dose and delivery route (Lacount et al., 1995; Lacount et al., 1996a; 1996b; Carlson et al., 2006; Carlson et al., 2007a).

Therefore, the objective of this study was to evaluate the lipotropic potential of L-carnitine in Holstein dairy cows during the transition period to lactation.

\section{Materials and methods}

\section{Ethical considerations}

The ethics committee for research of Universidad Nacional de Colombia (Medellín campus) approved this study (CEMED 200 communication, minute \# 13 , October $\left.5^{\text {th }}, 2010\right)$.

\section{Location}

The experiment was conducted at Paysandú Center, property of Universidad Nacional de Colombia, located in a tropical lower montane wet forest region according to the Holdridge classification of life zones (Espinal, 1977).

\section{Animals and diet}

A total of 21 Holstein cows between $2^{\text {nd }}$ and $6^{\text {th }}$ parity were used. Cows were between $d 260$ of gestation to d 20 postpartum. The cows grazed on kikuyu (Cenchrus clandestinum) grasslands and during pre-partum received $2 \mathrm{~kg} / \mathrm{d}$ of feed supplement containing 0,100 , or $200 \mathrm{~g}$ L-carnitine fumarate according to treatment (T0, T100, and T200, respectively). After calving, the cows received $6 \mathrm{~kg} / \mathrm{d}$ of feed supplement containing 0,100 , or 200 $\mathrm{g}$ of L-carnitine fumarate according to treatment. After the third postpartum day, milk production was recorded daily. When milk production was greater than $24 \mathrm{~L}$, one additional $\mathrm{kg}$ of base supplement without L-carnitine fumarate was supplied for every $4 \mathrm{~L}$ of milk produced. The nutritional composition of grass and feed supplements are described in Table 1.

Concentrations of crude protein (PC, Kjeldahl method, Icontec, 1999, standard NTC-4657), fiber in neutral detergent (FDN, AOAC standard 2002.04), fiber in acid detergent (FDA, AOAC 973.18 standard), ash (Cen, AOAC standard 942.05), ether extract [EE, Icontec (2002), NTC-668 standard] and lignin (Lig, potassium permanganate) in kikuyu grass (C. clandestinum), and feed supplements are presented in Table 2.

Ruminal degradability of L-carnitine fumarate was estimated through the in vitro incubation test described by Galvis (2016), who reported $89.7 \%$ degradability. L-carnitine fumarate $(99.59 \%$ L-carnitine fumarate, $58 \%$ of L-carnitine, Suzhou Vitajoy Biotech, China) was added to the basal feed formula. The inclusion levels of carnitine fumarate were 100 and $200 \mathrm{~g}$. According to Galvis (2016), these levels were used to achieve approximately 6 and $12 \mathrm{~g}$ L-carnitine available for intestinal absorption, respectively. The 
Table 1. Ingredients used in the formulation of the feed supplement.

\begin{tabular}{|c|c|c|}
\hline Ingredient (\%) & Prepartum & Postpartum \\
\hline Corn & 35 & 35 \\
\hline $\begin{array}{l}\text { Soybean meal ( } 46.5 \% \text { crude } \\
\text { protein) }\end{array}$ & 5 & 5 \\
\hline $\begin{array}{l}\text { Corn wet milled subproducts } \\
\text { (Ingredion }{ }^{\circledR} \text { ) }\end{array}$ & 30 & 30 \\
\hline Wheat bran & $\begin{array}{c}7.79 \text { to } \\
12.79\end{array}$ & 11.36 to 13.02 \\
\hline Palm oil & 2.5 & 2.5 \\
\hline Cane molasses & 7.0 & 7.0 \\
\hline Calcium carbonate & - & 2.0 \\
\hline Mono-dicalcium phosphate & - & 1.6 \\
\hline Sodium bicarbonate & - & 0.1 \\
\hline Sodium chloride & 1.0 & 1.0 \\
\hline Magnesium sulphate & 0.1 & 0.1 \\
\hline Sulfur & 0.2 & 0.2 \\
\hline Vitamin and mineral premix & 0.1 & 0.1 \\
\hline Chromic oxide & 1 & 0.4 \\
\hline L-carnitine fumarate & 5 or $10^{*}$ & 1.67 or $3.33^{*}$ \\
\hline Inhimol $p^{\circledR^{* *}}$ & 0.10 & 0.10 \\
\hline Mycoad $^{\circledR^{* *}}$ & 0.20 & 0.20 \\
\hline Adinox $\mathrm{p}^{\otimes^{* *}}$ & 0.01 & 0.01 \\
\hline Total & 100 & 100 \\
\hline
\end{tabular}

"These concentrations of L-carnitine fumarate guarantee 58 or $116 \mathrm{~g} / \mathrm{d}$ consumption of $L$-carnitine depending on the supplementation level (treatment T100 or T200), with 2 and $6 \mathrm{~kg} / \mathrm{d}$ consumption of feed supplement during prepartum and postpartum, respectively. ${ }^{*}$ Feed preservatives.

Table 2. Chemical composition of kikuyu grass (Cenchrus clandestinum) and feed supplement.

\begin{tabular}{lccc}
\hline $\begin{array}{c}\text { Chemical } \\
\text { fractions (\% dry } \\
\text { matter) }\end{array}$ & $\begin{array}{c}\text { Kikuyu } \\
\text { grass }\end{array}$ & Feed supplement \\
\cline { 3 - 4 } & & Prepartum & Postpartum \\
\hline Lignin & 4.32 & 2.4 & 2.43 \\
ADICP & 1.82 & 0.70 & 0.53 \\
NDICP & 5.24 & 1.40 & 1.43 \\
Ash & 9.62 & 7.96 & 10.0 \\
ADF & 32.0 & 9.1 & 8.03 \\
NDF & 61.6 & 27 & 24.9 \\
Ether extract (EE) & 2.11 & 5.72 & 6.08 \\
Crude protein (CP) & 17.3 & 16.8 & 15.4 \\
NSC & 14.6 & 43.92 & 45.05 \\
Chromic oxide & - & 0.42 & 0.17 \\
\hline
\end{tabular}

ADICP: Acid detergen insoluble crude protein; NDICP: Neutral detergen insoluble crude protein; NDF: Neutral detergent fiber; ADF: Acid detergent fiber; NSC: Non-structural carbohydrates $=100-(C P+N D F+$ ash + EE $)$ + CPIDN (NRC, 2001). experiment included seven cows per treatment. The experimental treatments were as follows: Control (T0), $100 \mathrm{~g} / \mathrm{d}$ L-carnitine fumarate (T100), and 200 $\mathrm{g} / \mathrm{d}$ L-carnitine fumarate (T200).

\section{Sampling and laboratory analysis}

Cows were weighed, blood-sampled (approximately $5 \mathrm{~mL}$ per cow), and body condition evaluated on $\mathrm{d} 270$ of pregnancy, on the day of calving, and on $\mathrm{d} 10$ and 20 postpartum. Liver biopsies were taken from each cow on d 270 of pregnancy and d 10 and 20 postpartum using previously described procedures (Galvis et al., 2016). Blood samples were taken from the base of the tail, thereby reducing pain or stress compared with other puncture sites such as the jugular vein. Local anesthesia was used and mild sedation was induced to collect liver biopsy samples through standard protocols (Waver et al., 2005). Serum was analyzed with spectrophotometric kits for NEFA, NEFA Fa-115 (Randox, London, UK), $\beta$-hydroxybutyrate ( $\beta$-HB) by Ranbut RB 1008 (Randox, London, UK), and urea by UREA/BUN Color (Biosystems, Barcelona, Spain) concentrations. Liver samples were analyzed for total carnitine, free carnitine and acylcarnitine following the methods described by Prieto et al. (2006). Liver triglycerides were analyzed with a previously described method by Galvis et al. (2016). A Genesys 10S UV-VIS spectrophotometer (Thermo Scientific, NY, USA) was used. Estimation of dry matter intake was previously described by Madrid et al. (2015).

Net energy for lactation (NEL), live weight change (WeightC), balances of metabolizable protein (MP) and rumen-degradable protein (RDP) were calculated using NRC Software (NRC, 2001)

\section{Statistical analysis}

Data from repeated measures over time were analyzed using PROC MIXED of the SAS statistical package, version 8 (SAS, 1999). Composite symmetric and first-order auto-regressive covariance structures were modeled following Littell et al. (1998). First-order autoregressive was the most suitable covariance structure for all variables. Calving number, corrected milk yield (305d-2X-ME) in the previous lactation, and body condition at the beginning of the experiment were used as covariates. Mean comparison was performed using 
the LSD test. Statistical differences were considered at $\mathrm{p}$ $<0.05$. The statistical model included the fixed effects of treatment, sampling period and the interaction between treatment and sampling period.

\section{Results}

No interactions were observed between treatments and sampling periods for any of the variables (blood concentrations of NEFA, $\beta$-HB and urea, balances of NEL, MP and RDP, WeightC and hepatic concentrations of triglycerides, total carnitine, free carnitine and acyl-carnitine; $\mathrm{p}>0.05$ ). None of the covariates [calving number, corrected milk yield (305d-2X-ME) in the previous lactation, and body condition at the beginning of the experiment] had a significant effect $(\mathrm{p}>0.05)$. Table 3 shows the nutritional balance and plasma indicators for each treatment. There were no significant differences $(p>0.05)$ between treatments for NEFA, $\beta$-HB, NEL, MP, RDP, and WeightC. In contrast, blood urea concentrations were significantly lower in the control treatment $(\mathrm{T} 0 ; \mathrm{p}>0.05)$.

Table 4 shows plasma indicators and nutritional balance per sampling period. All variables presented significant differences $(p<0.05)$ between sampling periods. The ENL, MP, and RDP balances were significantly lower during postpartum. Blood concentrations of glucose and NEFA increased significantly at calving. Blood urea and $\beta$-HB were related to the variations of RDP and ENL in the different periods.

Table 3. Treatment means for nutritional balance and plasma indicators in Holstein cows fed increasing levels of L-carnitine fumarate.

\begin{tabular}{lccccc}
\hline \multicolumn{1}{c}{ Variable } & T0 & T100 & T200 & SEM & p-value \\
\hline NEFA $(\mathrm{mMol} / \mathrm{L})$ & $0.152^{a}$ & $0.156^{a}$ & $0.115^{a}$ & 0.2374 & 0.39 \\
$\beta$-HB $(\mathrm{mMol} / \mathrm{L})$ & $0.680^{a}$ & $0.904^{a}$ & $0.830^{a}$ & 0.082 & 0.16 \\
Urea $(\mathrm{mg} / 100 \mathrm{~mL})$ & $29.95^{a}$ & $40.58^{b}$ & $37.28^{b}$ & 2.18 & 0.0088 \\
NEL $(\mathrm{Mcal} / \mathrm{d})$ & $-1.33^{a}$ & $-0.65^{a}$ & $-1.39^{a}$ & 1.87 & 0.95 \\
MP $(\mathrm{g} / \mathrm{d})$ & $58.75^{a}$ & $38.30^{a}$ & $-58.66^{a}$ & 76.54 & 0.52 \\
RDP $(\mathrm{g} / \mathrm{d})$ & $34.28^{a}$ & $18.54^{a}$ & $28.39^{a}$ & 6.06 & 0.19 \\
WeightC $(\mathrm{kg} / \mathrm{d})$ & $-0.357^{a}$ & $-0.180^{a}$ & $-0.382^{a}$ & 0.339 & 0.90 \\
\hline
\end{tabular}

Means with different superscript letters $\left({ }^{a, b}\right)$ within the same row indicate significant difference $(p<0.05)$. T0: Control; T100: $100 \mathrm{~g} / \mathrm{d} \mathrm{L}$-carnitine fumarate; T200: $200 \mathrm{~g} / \mathrm{d}$ L-carnitine fumarate; SEM: Standard error of the mean; NEFA: Non-esterified fatty acid; $\beta$-HB: $\beta$-hydroxybutyrate; NEL: Net energy for lactation; MP: Metabolizable protein balance; RDP: rumen-degradable protein; WeightC: live weight change.

Table 4. Sampling-period means for nutritional balance and plasma indicators in Holstein cows.

\begin{tabular}{|c|c|c|c|c|c|c|}
\hline Variable & $\begin{array}{l}10 \text { days } \\
\text { Prepartum }\end{array}$ & Partum & $\begin{array}{c}10 \text { days } \\
\text { Postpartum }\end{array}$ & $\begin{array}{c}20 \text { days } \\
\text { Postpartum }\end{array}$ & SEM & p-value \\
\hline NEFA (mMol/L) & $0.109^{a}$ & $0.246^{b}$ & $0.118^{a}$ & $0.091^{a}$ & 0.018 & $<0.0001$ \\
\hline$\beta-\mathrm{HB}(\mathrm{mMol} / \mathrm{L})$ & $0.692^{a}$ & $0.703^{a}$ & $0.890^{b}$ & $0.934^{b}$ & 0.074 & 0.05 \\
\hline Glucose (mg/100mL) & $60.23^{a}$ & $72.91^{b}$ & $47.05^{a}$ & $46.57^{a}$ & 5.95 & 0.004 \\
\hline Urea $(\mathrm{mg} / \mathrm{dL})$ & $37.37^{b}$ & $39.56^{b}$ & $31.29^{a}$ & $35.54^{a b}$ & 1.96 & 0.008 \\
\hline NEL (Mcal/d) & $4.64^{b}$ & - & $-4.17^{a}$ & $-3.84^{a}$ & 1.94 & 0.0005 \\
\hline MP (g/d) & $334.94^{b}$ & - & $-191.51^{a}$ & $-105.04^{a}$ & 76.97 & $<0.0001$ \\
\hline $\operatorname{RDP}(g / d)$ & $93.50^{b}$ & - & $-2.32^{a}$ & $-9.97^{a}$ & 4.46 & $<0.0001$ \\
\hline WeightC $(\mathrm{kg} / \mathrm{d})$ & $0.715^{b}$ & - & $-0.851^{a}$ & $-0.783^{a}$ & 0.361 & 0.001 \\
\hline
\end{tabular}

Means with different superscript letters $\left({ }^{a, b}\right)$ within the same row indicate significant difference $(p<0.05)$. SEM: Standard error of the mean; NEFA: Nonesterified fatty acid; $\beta$-HB: $\beta$-hydroxybutyrate; NEL: Net energy for lactation; MP: Metabolizable protein balance; RDP: Rumen-degradable protein; WeightC: Live weight change. 
There were no significant differences $(p>0.05)$ between treatments with respect to liver concentration of acylcarnitine, free carnitine, and total carnitine. In contrast, hepatic triglyceride concentration was significantly lower $(\mathrm{p}<0.05)$ in T200 (Table 5).

Table 5. Treatment means for hepatic concentration of triglycerides, acylcarnitine, and total carnitine in Holstein cows fed increasing levels of L-carnitine fumarate.

\begin{tabular}{lccccc}
\hline \multicolumn{1}{c}{ Variable } & T0 & T100 & T200 & SEM & p-value \\
\hline $\begin{array}{l}\text { Triglycerides } \\
\text { (mg/g fresh liver) }\end{array}$ & $37.60^{b}$ & $41.49^{b}$ & $27.62^{a}$ & 3.57 & 0.034 \\
$\begin{array}{l}\text { Total carnitine } \\
\text { (nMol/g fresh liver) }\end{array}$ & $114.70^{a}$ & $117.94^{a}$ & $125.49^{a}$ & 32.28 & 0.92 \\
$\begin{array}{l}\text { Free carnitine } \\
\text { (nMol/g fresh liver) }\end{array}$ & $70.32^{a}$ & $90.79^{a}$ & $92.58^{a}$ & 22.54 & 0.87 \\
$\begin{array}{l}\text { Acyl-carnitine } \\
\text { (nMol/g fresh liver) }\end{array}$ & $43.64^{a}$ & $34.95^{a}$ & $39.897^{a}$ & 14.18 & 0.50 \\
\hline
\end{tabular}

Means with different superscript letters $\left({ }^{a}, b\right)$ within the same row indicate significant difference $(p<0.05)$. T0: Control. T100: $100 \mathrm{~g} / \mathrm{d}$ L-carnitine fumarate. T200: $200 \mathrm{~g} / \mathrm{d}$ L-carnitine fumarate. SEM: Standard error of the mean.

No significant differences were found between sampling periods for hepatic triglyceride concentrations, acylcarnitine, free carnitine, and total carnitine $(\mathrm{p}>0.05$; Table 6$)$.

Table 6. Sampling period means for hepatic triglycerides and carnitine concentrations in Holstein cows.

\begin{tabular}{|c|c|c|c|c|c|}
\hline Variable & $\begin{array}{l}10 \text { days } \\
\text { Prepartum }\end{array}$ & $\begin{array}{c}10 \text { days } \\
\text { Postpartum }\end{array}$ & $\begin{array}{l}20 \text { days } \\
\text { Postpartum }\end{array}$ & SEM & $p$-value \\
\hline $\begin{array}{l}\text { Triglycerides } \\
\text { (mg/g fresh liver) }\end{array}$ & $37.59^{a}$ & $33.13^{a}$ & $35.98^{\mathrm{a}}$ & 2.84 & 0.48 \\
\hline $\begin{array}{l}\text { Total carnitine } \\
\text { (nMol/g fresh liver) }\end{array}$ & $128.39^{a}$ & $114.92^{a}$ & $101.37^{a}$ & $25.86^{a}$ & 0.64 \\
\hline $\begin{array}{l}\text { Free carnitine } \\
\text { (nMol/g fresh liver) }\end{array}$ & $102.87^{a}$ & $72.53^{a}$ & $80.90^{a}$ & 21.46 & 0.61 \\
\hline $\begin{array}{l}\text { Acyl-carnitine } \\
\text { (nMol/g fresh liver) }\end{array}$ & $31.14^{a}$ & $36.07^{a}$ & $34.67^{a}$ & 9.22 & 0.84 \\
\hline
\end{tabular}

Means with different superscript letters $\left({ }^{a, b}\right)$ within the same row indicate significant difference $(p<0.05)$. SEM: Standard error of the mean.

\section{Discussion}

Significant differences $(\mathrm{p}<0.05)$ were found in NEFA and $\beta$-HB concentrations within the different periods. The NEFA values around calving were significantly higher. This is due to the decrease in dry matter intake that occurs together with the increase of cortisol (Weber et al., 2013), which induces NEFA mobilization from the adipose tissue. The $\beta$-HB values at 10 days postpartum were significantly lower than the values found at $\mathrm{d} 10$ and 20 postpartum; increased milk production leads to energy deficit and NEFA oxidation, which combines with increasing glucose deficit leading to greater $\beta$-HB concentration. The relationship between NEFA and $\beta$-HB at calving was not evident, because the increase in gluconeogenesis induced by cortisol during this period (Hammon et al., 2005) increased glucose levels, preventing the elevation of $\beta$-HB values (Erfle et al., 1971). Plasma urea values were higher at $d 10$ prepartum and at calving day. High values during prepartum can be explained by a higher rumen degradable protein balance during this period (Putnam and Varga, 1998). The high plasma urea values around calving result from the intense catabolism of amino acids destined for cortisol-induced 
gluconeogenesis (Hammon et al., 2005). This increases oxidative deamination of amino acids, generating ammonium, which is mostly transformed into urea (Madsen, 1983).

L-carnitine fumarate supplementation significantly increased plasma urea concentration (Table 3). According to other reports, administration of L-carnitine in sheep (Chapa et al., 1998; 2001) and growing bovines (White et al., 2001) increases plasma ammonium removal, possibly due to its conversion to urea. Most reports about carnitine effects on urea synthesis have been conducted in species other than bovines. Studies on monkeys with induced hyperammonemia (Ratnakumar et al., 1993; O'Connor et al., 1987a, O'Connor et al., 1987b), and on rat hepatocytes (Takeuchi et al., 1988; Tomomura et al., 1996) reported decreased hyperammonemia and increased urea synthesis in response to carnitine, which was attributed to several mechanisms (i.e. changes in enzyme expression, in enzymatic activity, and in the concentration of allosteric effectors). Indeed, a decrease in the carnitine-dependent fatty acid transport system causes an accumulation of acyl-CoA molecules in the cytosol, and these metabolites inhibit the urea cycle (Malaguarnera, 2013). Therefore, we suggest that the rise in plasma urea observed in animals supplemented with L-carnitine fumarate could be due to a significant increase in the urea cycle activity induced by L-carnitine. The first study with L-carnitine in cows indicated that carnitine infusion in the blood significantly increases blood concentrations of total ketones (Erfle et al., 1971), accounting for an increase in fatty acid oxidation. Researchers found that $\beta$-HB concentrations tended to be higher ( $p=0.07)$ in cows receiving 10 and $20 \mathrm{~g}$ carnitine available for intestinal absorption (Carlson et al., 2007a). However, the amount of ketone production in response to carnitine depends on the availability of carbohydrates (Erfle et al., 1971). In the present study, elevation in $\beta$-HB concentrations was not observed, possibly due to the amount of available glucose (Table 4), so that the increase of fatty acid oxidation could be significant, but without apparent changes in $\beta$-HB concentration.

Liver concentration of triglycerides (Tables 5 and 6) was low, according with levels reported by other authors (Kalaitzakis et al., 2007; Starke et al., 2010; Gross et al., 2013). Supplementation with $200 \mathrm{~g} / \mathrm{d}$ L-carnitine fumarate significantly decreased hepatic triglyceride concentrations (Table 5), possibly due to a higher rate of fatty acid oxidation by the liver, decreasing their availability for esterification. Liver slices from cows during early lactation showed that carnitine increases total palmitate oxidation and decreases its esterification (Drackley et al., 1991b). In rat liver cells, distribution of fatty acids between esterification and oxidation is regulated by cytoplasmic concentrations of glycerol-phosphate or carnitine, respectively (Bremer et al., 1978). Carlson et al. (2007a) found that carnitine supply during early lactation decreases hepatic triglycerides and increases plasma concentrations of $\beta-\mathrm{HB}$, even when liver triglycerides are low in the control treatment. Hepatic concentrations of the different forms of L-carnitine were lower (Tables 5 and 6) than those reported in other studies (Erfle et al., 1971; LaCount et al., 1995; Carlson et al., 2007a; 2007b) and were not affected by supplementation with L-carnitine fumarate. Other studies were able to increase hepatic carnitine concentrations only when they gave doses higher than $10 \mathrm{~g} / \mathrm{d}$ carnitine available for intestinal absorption, or $20 \mathrm{~g} / \mathrm{d}$ in abomasal infusion (Carlson et al., 2007a; 2007b). The carnitine transport system in the liver has been characterized in human, rat and mouse (Ramsay et al., 2001). Carnitine uptake by the liver depends on relatively high carnitine concentration in the blood, since carnitine enters the liver through OCTN2 (organic cation transporter 2), a carrier with high $\mathrm{Km}$ (Michaelis-Menten constant) for carnitine $(\mathrm{Km}=5.6 \mathrm{mM}$ : Christiansen and Bremer, 1976), thus the liver takes carnitine from the blood when its concentration is significantly rised. It is possible that the low amounts of carnitine available for intestinal absorption in our study did not increase enough plasma carnitine concentration to achieve a significant increase in its entrance to the liver, thus its concentration was not increased.

In conclusion, supplementation with $200 \mathrm{~g} / \mathrm{d}$ L-carnitine fumarate significantly reduces hepatic triglyceride concentration, even when NEFA and hepatic triglycerides are low. Hepatic triglycerides decreased in response to carnitine supplementation possibly due to increased fatty acid oxidation. Supplementation with L-carnitine increases blood urea levels possibly due to an increase in the 
conversion of ammonia into urea. Both effects of the supplementation with L-carnitine can be beneficial for the metabolic health of dairy cows under energy deficit and dietary excess of rumen degradable protein.

\section{Aknowledgements}

This study was funded by Colciencias (call 521, Project number: 1118-521-28602) and co-financed by the Universidad Nacional de Colombia, Medellin campus

\section{Conflicts of interest}

The authors declare they have no conflicts of interest with regard to the work presented in this report.

\section{References}

AOAC. Association of Official Analytical Chemists International (AOAC). Official methods of analysis of AOAC International. $18^{\text {th }}$ edition. Maryland, USA, 2005.

Bell AW, Burhans WS, Overton TR. Protein nutrition in late pregnancy, maternal protein reserves and lactation performance in dairy cows. Proc Nutr Soc 2000; 59:119-126.

Bremer J, Christiansen RZ, Boreebaek, B. Regulation of partition of free fatty acids between triglyceride synthesis and $\beta$-oxidation in liver. In: Esmann V, editor. Regulatory Mechanisms of Carbohydrate Metabolism. Proceedings of the 11th meeting of the Federation of European Biochemical Societies; 1977; Copenhagen, Denmark. Pergamon press; 1978. p.161-170.

Carlson DB, Litherland NB, Dann HM, Woodworth JC, DrackleyJK. Metabolic effects of L-carnitine infusion and feed restriction in lactating Holstein cows. J Dairy Sci 2006; 89:4819-4834.

Carlson DB, McFadden JW, D'Angelo A, Woodworth C, Drackley JK. Dietary L-carnitine affects periparturient nutrient metabolism and lactation in multiparous cows. J Dairy Sci 2007a; 90:3422-3441.

Carlson DB, Woodworth JC, Drackley JK. Effect of L-carnitine infusion and feed restriction on carnitine status in lactating Holstein cows. J Dairy Sci 2007b; 90:2367-2376.

Chapa AM, Fernandez JM, White TW, Bunting LD, Gentry LR, Ward TL, Blum SA. Infuence of intravenous L-carnitine administration in sheep preceding an oral urea load drench. J Anim Sci 1998; 76:2930-2937.

Chapa AM, Fernandez JM, White TW, Bunting LD, Gentry LR, Lovejoy JC, Owen KQ. Influence of dietary carnitine in growing sheep fed diets containing non-protein nitrogen. Small Rumin Res 2001; 40:13-28.
Christiansen RZ, Bremer J. Active transport of butyrobetaine and carnitine into isolated liver cells. Biochim Biophys Acta 1976; 448:562-577.

Dann HM, Varga GA, Putnam DE. Improving energy supply to late gestation and early postpartum dairy cows. J Dairy Sci 1999; $82: 1765-1778$.

Drackley JK, Beitz DC, Young JW. Regulation of in vitro palmitate oxidation in liver from dairy cows during early lactation. J Dairy Sci 1991a; 74:1884-1892.

Drackley JK, Beitz DC, Young JW. Regulation of in vitro metabolism of palmitate by carnitine and propionate in liver from dairy cows. J Dairy Sci 1991b; 74:3014-3024.

Erfle JD, Sauer FD, Fisher LJ. Effect of Infusion of carnitine and glucose on blood glucose, ketones, and free fatty acids of ketotic cows. J Dairy Sci 1971; 54:673-680.

Espinal LS. Zonas de vida o formaciones vegetales de Colombia: Mapas.Instituto Geográfico Agustin Codazzi 1977. 20 mapas.

Galvis GR. Efecto de la complementación con metionina-colina y L-carnitina en vacas Holstein durante el periodo de transición sobre la acumulación hepática de triglicéridos. Tesis Doctorado en Ciencias Agrarias. Facultad de Ciencias Agrarias, Universidad Nacional de Colombia, Medellín, 2016. p. 106.

Galvis GR, Ramirez NF, Giraldo A. Extracción, cuantificación y distribución de las principales fracciones lipídicas en pequeñas biopsias de hígado de vacas en el periodo de transición. Rev CES Med Vet y Zootec 2016; 11(1):26-38.

Galvis RD, Valencia D, Correa HJ, Ramírez NF, Torres J. Efecto de niveles crecientes de nitrógeno no protéico dietario sobre la concentración de precursores gluconeogénicos en hígado bovino. Rev Fac Nac Agron 2010; 63(1): 5363-5372.

Gross J, Schwarz F, Eder K, Van Dorland A, Bruckmaier RM. Liver fat content and lipid metabolism in dairy cows during early lactation and during a mid-lactation feed restriction. J Dairy Sci 2013; 96:5008-5017.

Hammon HM, Philipona C, Zbinden Y, Blum JW, Donkin SS. Effects of dexamethasone and growth hormone treatment on hepatic gluconeogenic enzymes in calves. J Dairy Sci 2005; $88: 2107-2116$.

Icontec. Norma técnica colombiana NTC 4657. Alimento para animales. Determinación del contenido de nitrógeno y cálculo del contenido de proteína cruda. Método Kjeldahl. Instituto Colombiano de Normas Técnicas y Certificación, 1999.

Icontec. Norma técnica colombiana NTC 668. Alimentos y materias primas. Determinación de los contenidos de grasa y fibra cruda. Instituto Colombiano de Normas Técnicas y Certificación, 2002.

Kalaitzakis E, Roubies N, Panousis N, Pourliotis K, Kaldrymidou E, Karatzias H. Clinicopathologic evaluation of hepatic lipidosis in periparturient dairy cattle. J Vet Intern Med 2007; 21:835-845.

Lacount DW, Drackley JK, Weigel DJ. Responses of dairy cows during early lactation to ruminal or abomasal administration of L-carnitine. J Dairy Sci 1995; 78:1824-1836. 
Lacount DW, Emmert LS, Drackley JK. Dose Response of dairy cows to abomasal administration of four amounts of L-carnitine. J Dairy Sci 1996a; 79:591-602.

Lacount DW, Ruppertt DL, Drackley JK. Ruminal degradation and dose response of dairy cows to dietary L-carnitine. J Dairy Sci 1996b; 79:260-269.

Littell RC, Henry PR, Ammerman CB. Statistical analysis of repetead measures using SAS procedures. J Animal Sci 1998; 76:1216-1231.

Madrid LV, Correa HJ, Galvis RD. Efecto de la inclusión de fumarato de L-carnitina sobre el consumo de materia seca, en vacas Holstein durante el periodo de transición a la lactancia. Rev CES Med Vet y Zootec 2015; 10(2):193-202.

Madsen A. Metabolism in liver cells. In: Riis PM, editor: Dynamic Biochemistry of Animal Production. Amsterdam: Elsevier Science Publishers B.V; 1983. p. 53-74.

Malaguarnera M. Acetyl-L-carnitine in hepatic encephalopathy. Metab Brain Dis 2013; 28:193-199.

NRC. Nutrient Requirements of Dairy Cattle: $7^{\text {th }}$ Revised Edition. Subcommittee on Dairy Cattle Nutrition, Committee on Animal Nutrition, National Research Council. National Academy Press, 2001. p. 381.

O'Connor JE, Costell M, Grisolía S. The potentiation of ammonia toxicity by sodium benzoate is prevented by L-carnitine. Biochem Biophy Res Com 1987b; 145(2):817-824.

O’Connor JE, Costell M, Míguez MO, Portolés M, Grisolía S. Effect of L-carnitine on ketone bodies, redox state and free amino acids in the liver of hyperammonemic mice. Biochem Pharm 1987a; 36(19): 3169-3173.

Prieto JA, Andrade F, Aldámiz-Echevarría L, Sanjurjo P. Determination of free and total carnitine in plasma by an enzymatic reaction and spectrophotometric quantitation spectrophotometric determination of carnitine. Clin Biochem 2006; 39:1022-1027.

Putnam DE, Varga GA. Protein density and its influence on metabolite concentration and nitrogen retention by Holstein cows in late gestation. J Dairy Sci 1998; 81:1608-1618.
Ramsay RR, Gandour RD, Van der Leij FR. Molecular enzymology of carnitine transfer and transport. Biochim Biophys Acta 2001; 1546:21-43.

Ratnakumar LI, Qureshi IA, Butterworth RF. Effect of L-carnitine on cerebral and hepatic energy metabolites in congenitally hyperammonemic sparse-fur mice and its role during benzoate therapy. Metabolism 1993; 42(8):1039-1046.

SAS $^{\circledR}$, Statistical Analysis Systems. SAS/STAT User's Guide. Version 8. Cary, NC (USA): SAS Institute Inc., 1999.

Starke A, Haudum A, Busche R, Beyerbach M, Dänicke S. Technical note: Analysis of total lipid and triacylglycerol content in small liver biopsy samples in cattle. J Anim Sci 2010; 88: 2741-2750.

Takeuchi T, Sugimoto T, Nishida N, Kobayashi Y. Protective effect of D-L-carnitine on valproate-induced hyperammonemia and hypoketonemia in primary cultured rat hepatocytes. Biochem Pharm 1988; 37(11):2255-2258.

Tomomura M, Tomornura A, Dewan MD, Abdullah AM, Saheki T. Long-chain fatty acids suppress the induction of urea cycle enzyme genes by glucocorticoid action. FEBS Letters 1996; 399:310-312.

Waver D, St. Jean G, Steiner A. Bovine Surgery and lameness. $2^{\text {nd }}$ edition. Oxford: David Weaver, Adrian Steiner and Guy St Jean, editors; 2005. p. 132-133.

Weber C, Hametner A, Tuchscherer B, Losand E, Kanitz W, Otten SP, Singh RM, Bruckmaier F, Becker F, Kanitz W, Hammon HM. Variation in fat mobilization during early lactation differently affects feed intake, body condition, and lipid and glucose metabolism in high-yielding dairy cows. J Dairy Sci 2013; 96:165-180.

White TW, Fernandez JM, Gentry GT, Gentry RL, DeRouen PT, Froetschel MA. Influence of urea alone or combined with fish solubles, fish meal, or feather meal in liquid supplement with and without L-carnitine on performance, ruminal, and metabolic parameters of weanling calves. Prof Anim Sci 2001; 17:145-153. 